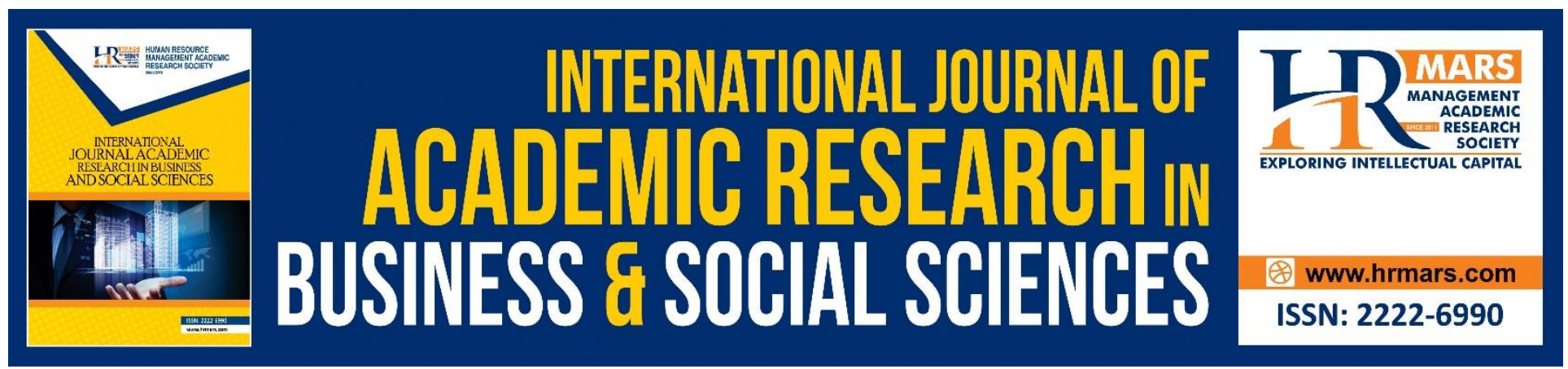

\title{
The Impact of the Integrated Talent Management on the Competitive Advantage in Multinational Corporations
}

Shirley Nagy Ibrahim, Adel Zayed

To Link this Article: http://dx.doi.org/10.6007/IJARBSS/v8-i7/4337

DOI: $\quad 10.6007 /$ IJARBSS/v8-i7/4337

Received: 21 May 2018, Revised: 16 July 2018, Accepted: 29 July 2018

Published Online: 03 August 2018

In-Text Citation: (Ibrahim \& Zayed, 2018)

To Cite this Article: Ibrahim, S. N., \& Zayed, A. (2018). The Impact of the Integrated Talent Management on the Competitive Advantage in Multinational Corporations. International Journal of Academic Research in Business and Social Sciences, 8(7), 221-237.

Copyright: (C) 2018 The Author(s)

Published by Human Resource Management Academic Research Society (www.hrmars.com)

This article is published under the Creative Commons Attribution (CC BY 4.0) license. Anyone may reproduce, distribute, translate and create derivative works of this article (for both commercial and non-commercial purposes), subject to full attribution to the original publication and authors. The full terms of this license may be seen

at: http://creativecommons.org/licences/by/4.0/legalcode

\section{Vol. 8, No. 7, July 2018, Pg. 221 - 237}

Full Terms \& Conditions of access and use can be found at http://hrmars.com/index.php/pages/detail/publication-ethics 


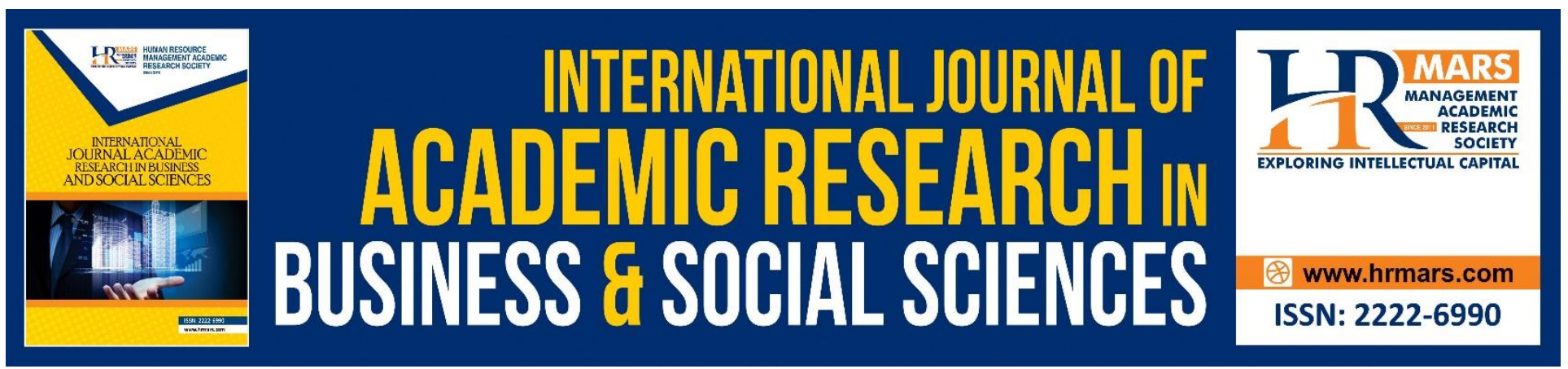

\title{
The Impact of the Integrated Talent Management on the Competitive Advantage in Multinational Corporations
}

\author{
Shirley Nagy Ibrahim \\ Faculty of Commerce, Cairo University, Egypt, PhD Candidate \\ Email: Shirley@aou.edu.eg \\ Prof. Dr. Adel Zayed \\ Faculty of Commerce, Cairo University, Address: 1 Gamaa Street, Giza, Egypt. \\ Email: Dradelmzayed@gmail.com
}

\section{Abstract}

This study tried to identify the impact of the integrated talent management on improving the business competitive advantage in multinational food and beverage companies in Cairo, Egypt. Convenience sampling is used as the sampling strategy. This study is based on questionnaire and data collected from 219 employees and managers in multi-national corporations for food and beverage located in greater Cairo. The purpose of this study is to design conceptual model of integrated talent management system in order to manage talent effectively. It will focus on discussing the process cycle in managing talent, starting from the business strategic goals until it gains the required competitive advantage. Results revealed that there is a significant positive relationship between integrating the business strategies and business culture with the talent management and improving the business competitive advantage.

Keyword: Business Strategy, Business Culture, Competitive Advantage, Integrating Talent Management

\section{Introduction}

The rise of the knowledge economy and the new generation of workforce mean that the "traditional human resources management is no longer a sufficient tool" (Tansley, 2011). It requires introduction of a new generation of human resources management - talent management (TM). Business leaders understand that having the right people in the right place at the right time to maximize business opportunities has become the most important factor in ensuring ongoing organizational success and sustain the competitive advantage (Wahyuningtyas, 2014). While managing employees effectively is obviously important, it's the acquisition, allocation, development, 
INTERNATIONAL JOURNAL OF ACADEMIC RESEARCH IN BUSINESS AND SOCIAL SCIENCES Vol. 8, No. 7, July 2018, E-ISSN: 2222-6990 @ 2018 HRMARS

retention and succession of the most important and value adding people can be the best to create competitive advantage (Ingham, 2006).

Cappelli (2008) mentioned that most of the currently used processes of talent management were created almost half a century ago, and now the time has come to create a new model. The organizations need to rethink their approaches to talent management. Although there are a variety of approaches to talent management the researcher believes that the integrated talent management is the paradigm shift for organization and can be defined as an innovative and holistic approach to effective talent management which enables an organization to respond to the ongoing changes in business environment adequately and flexibly thereby it can improve its competitive advantage (Collings and Mellahi, 2009 ; Egerová, 2013).

Previous researchers tried to integrate the talent management with a specific organizational aspect, in order to improve the organization competitive advantage and maximize the utilization of their talented employees. Researchers (Ulrich, 2008; Avedon and Scholes, 2010; Jackson, 2010; Nouman et al., 2015) point out that, by integrating the firm's human resources into the strategies of the business, it becomes a source of competitive advantage. High potential employees at all levels enhance the achievement of the strategic business objectives (Avedon and Scholes, 2010). Yapp (2009) added that talent management is required by the fact that it has been found to lead to higher corporate profits when it is connected to the corporate strategy. Other scholars (Al Ariss et al., 2014; Bali and Dixit, 2016) revealed that integrating the business culture with the talent management is a mandatory step in gaining a competitive advantage. Egerová (2013) conclude her paper by developing a talent mindset which beliefs that having better talents at all levels allow business to improve its performance, innovate, and thus gain competitive advantage.

Scullion \& Colings (2012) conclude their paper by "while firms tend to recognize the importance of talent management, they often do not manage it effectively and they lack to gain the most benefit from it". Nouman et al., (2015) Added that organizations cannot remain competitive, if they are not able to; identify, attract, develop, and retain the talented workers within the business context. Based on these gaps, it is clear that there is a need to develop a deeper understating of the integrated talent management.

This paper tried to resolve the issue of "Is it possible to integrate the previous models in order to build a comprehensive model that is enhancing the advantages and eliminating the disadvantages of the previous models to develop a sustain competitive advantage"

\section{Literature Review}

\section{Talent}

The first issue which should be considered before starting the talent management implementation is the term talent. Organizations and talent management professionals need to understand who they regard as talented people before starting the developing and implementing the talent management policies and practices (Zhang and Bright, 2012).

Tansley (2011) identify that despite of the substantial research that had been undertaken on talent management as a human resources initiative, people are rarely precise about what they mean by the term "talent" in organizations and the implications of defining talent for talent management practice. 
INTERNATIONAL JOURNAL OF ACADEMIC RESEARCH IN BUSINESS AND SOCIAL SCIENCES Vol. 8, No. 7, July 2018, E-ISSN: 2222-6990 @ 2018 HRMARS

There is no universal managerial talent definition; different organizations gave talent definitions with different focus (Zhang and Bright, 2012). Some "companies do not even know how to define 'talent', let alone how to manage it"

However, choosing a definition of talent is not an easy task, not merely because there are a number of ways in which talent may be defined within a particular organization. Some organizations find greater value in formulating their own meaning of what talent is, than accepting universal or prescribed definitions.

For the purpose of this study, the researcher defined the talented employee as "a person of high potential, who stands out as far as his knowledge, skills, experience, capabilities and development potential are concerned and who contributes to his organization's efficiency increase".

\section{Talent Management}

The term "talent management" is perceived and defined in various ways. For somebody it is the management of important or talented individuals, while others understand it as managing people in general - i.e. on the assumption that everyone has talent that should be identified and applied. Different authors define Talent Management (TM) from different perspectives:

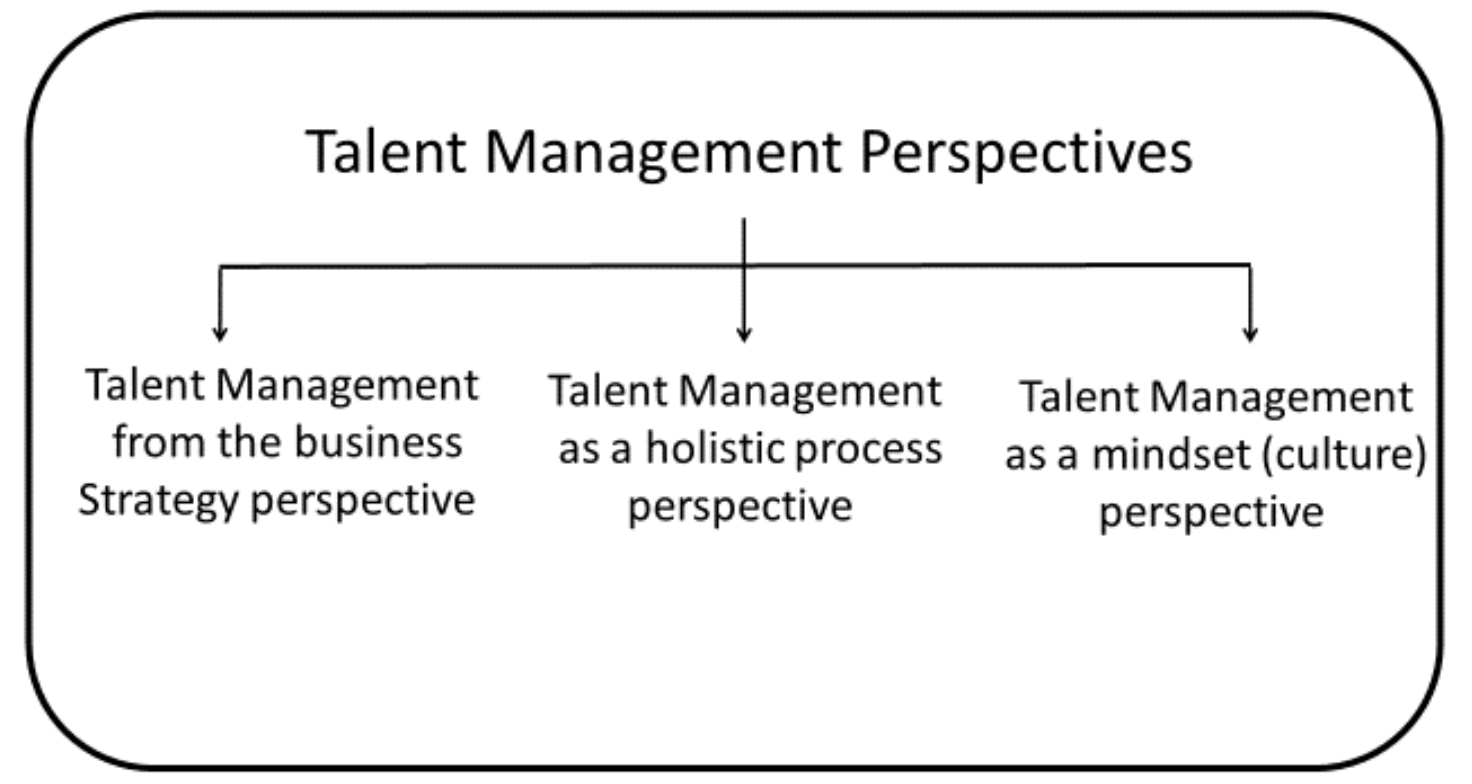

Figure -1

Different Talent Management Perspectives

Source: adopted by the researcher

\section{Talent Management as a source of sustained competitive advantage}

Mwailu \& Mercer at 1983 used the resource-based view (RBV) as a basis for the competitive advantage of a firm lies primarily in the application of a bundle of valuable tangible or intangible resources at the firm's disposal developed since the mid-eighties (Jackson, 2010 \& Nouman et al., 2015).

Barney, (1991) illustrated that in order to transform a short-run competitive advantage into a sustained competitive advantage exists only when other firms are incapable of duplicating the benefits of a competitive advantage. Therefore, four criteria must be attributable to the resource in order for it to provide a sustained competitive advantage: I) the resource must add positive value to 
INTERNATIONAL JOURNAL OF ACADEMIC RESEARCH IN BUSINESS AND SOCIAL SCIENCES

Vol. 8, No. 7, July 2018, E-ISSN: 2222-6990 @ 2018 HRMARS

the firm, 2) the resource must be unique or rare among current and potential competitors, 3) the resource must be poorly imitable, and 4) the resource cannot be substituted with another resource by competing firms.

Business leaders recognize that employee's knowledge, skills and abilities are a critical source to organizations competitive advantage. The employees are the company's most important critical asset and access to success (Sheehan, 2012). To gain profitability and competitive advantages, human resource development has become a priority for organizations around the world (Collings \& Mellahi, 2009). While talent-management practices can create the most permanent competitive advantages, new technologies and innovations can be easily be simulated by competitors and generate only temporary competitive advantages. Sustained competitive advantage comes from effective talent management practices (Tarique and Schuler, 2010). Nouman et al., (2015) build their paper on "talent based theory" which states that the talent is the only resource which may help in gaining and maintain the competitive advantage, and, therefore organizations must put a focus on attracting and maintaining the talented work force.

According to Cheng et al., (2011) a firm which implementing a differentiation strategy is able to achieve a competitive advantage over its rivals because of its ability to develop entry barriers to potential competitors by building customer and brand loyalty (Ashton \& Morton, 2005), through quality offerings, customer satisfaction, advertising and marketing techniques. Thus, a firm that implements a differentiation strategy enjoys the benefit of price-inelastic demand for its product or service.

Moreover, Effective talent management involves positioning the right person in the right jobs. This ensures that the employees maximize their talent for optimal success of the organization and achieving its goal (McCauley and Wakefield, 2006). Building and enhancing employee potential will not only benefit employees, it will also support the organization in meeting its goals and objectives.

\section{Integrate Talent Management (TM) with business strategy}

Putting the talent management into business context is perquisite for success, in building a talent strategy business must first acquire a deep understanding of the business and its interdependencies. Failing to accurately understand the business context usually results in an unconnected talent strategy, poor use of resources and less optimal performance (Bergeron, 2004).

Each organization needs to develop its own unique talent strategy. To be successful, the talent strategy must be aligned with an organization's business strategy and human capital context (Heinen \& O'Neill, 2004). While Stahl et al., (2012) identify the business strategy as the natural starting point for thinking about talent managemnt, given what kind of talent do the businesses need. After formulating the business strategies and determining its strategic goals, business has to formulate talent mangement identification strategy in order to identify the potential capabilities and qualifications to achive these goals and add value to the business (Karunathilaka et al., 2015).

It is important to understand that talent management cannot be isolated from the company's business strategy. Talent Management is a part of the human resources management strategy and therefore also a part of the business strategy. The talent management strategy must align with the business strategy of a company, (Langenegger, 2011) argued that talent management is understood 
as a sum of activities to support the business strategy. A sustainable strategy requires workforce engagement and an individual is more likely to work better and engage when his personal objectives and characteristics are aligned with the organization's strategy for growth and the organization's supportive structure and the firms want to exploit not just the most talented and capable architects, but also those most motivated to achieve the organization's objectives (Canavan, 2013).

Jackson (2010) argued that all organizations aim to achieve strategic objectives. This requires a clear understanding and linkage between these strategic goals and the key capabilities required for their achievement. To achieve sustainable competitive advantage organizations need two kinds of capabilities:

- Non-contingent capabilities are those capabilities which every organization needs, in varying degrees. These are the basics that will enable an organization to be "just as good" as its competitors. - Differentiating capabilities are those that distinguish one organization from another and can provide real competitive advantage.

He also illustrates that human capabilities however, are not only extremely difficult to build but are also difficult to copy. Their development tends to be linked with organizational culture, management style and many other contextual factors which are impossible to imitate. Management of talent must be understood in the context of the firm's strategic capabilities (William \& Slocum, 2012).

\section{Integrate Talent Management with Business Culture and Management Mindset}

Wahyuningtyas (2014) conclude his paper by the organizations that have the talent mindset culture will prioritize the development of existing employees in the organization so are expected to improve organizational performance indirectly. In order to build a talent mindset culture in organization, it must be begun from top level management in organization as a role model to all levels below them.

Business culture could be considered a source of the sustainable advantage. The culture supporting the processes and practices of talent management is a prerequisite of its successful integration in the organization (Egerová, 2013). All the talent management principles must be embedded in the business culture. The company has to exert effort to transform all the talent management principles and practices in the business and human resources practices as training programs and the selection process. The transformation should be done by means of incorporating the talent management principles into the existing business culture (Štefko and Sojka, 2014).

In connection with talent management the expression talent mindset is an important term. Talent mindset is a deep-rooted belief that having better talents at all levels allows your company to outperform its competitor (Hatum, 2010). It is the recognition that better talents pull all the other performance levers (Heinen \& O'Neill, 2004) and it does not only mean that people are organization's most important assets but it means a deep belief that better talent leads to better performance results and enhance the competitive advantage of any business (McCauley and Wakefield, 2006). This belief gives leaders the determination to strengthen their talent pool and the bravery to take brave action to do so. 
INTERNATIONAL JOURNAL OF ACADEMIC RESEARCH IN BUSINESS AND SOCIAL SCIENCES Vol. 8, No. 7, July 2018, E-ISSN: 2222-6990 @ 2018 HRMARS

\section{Theoretical Framework}

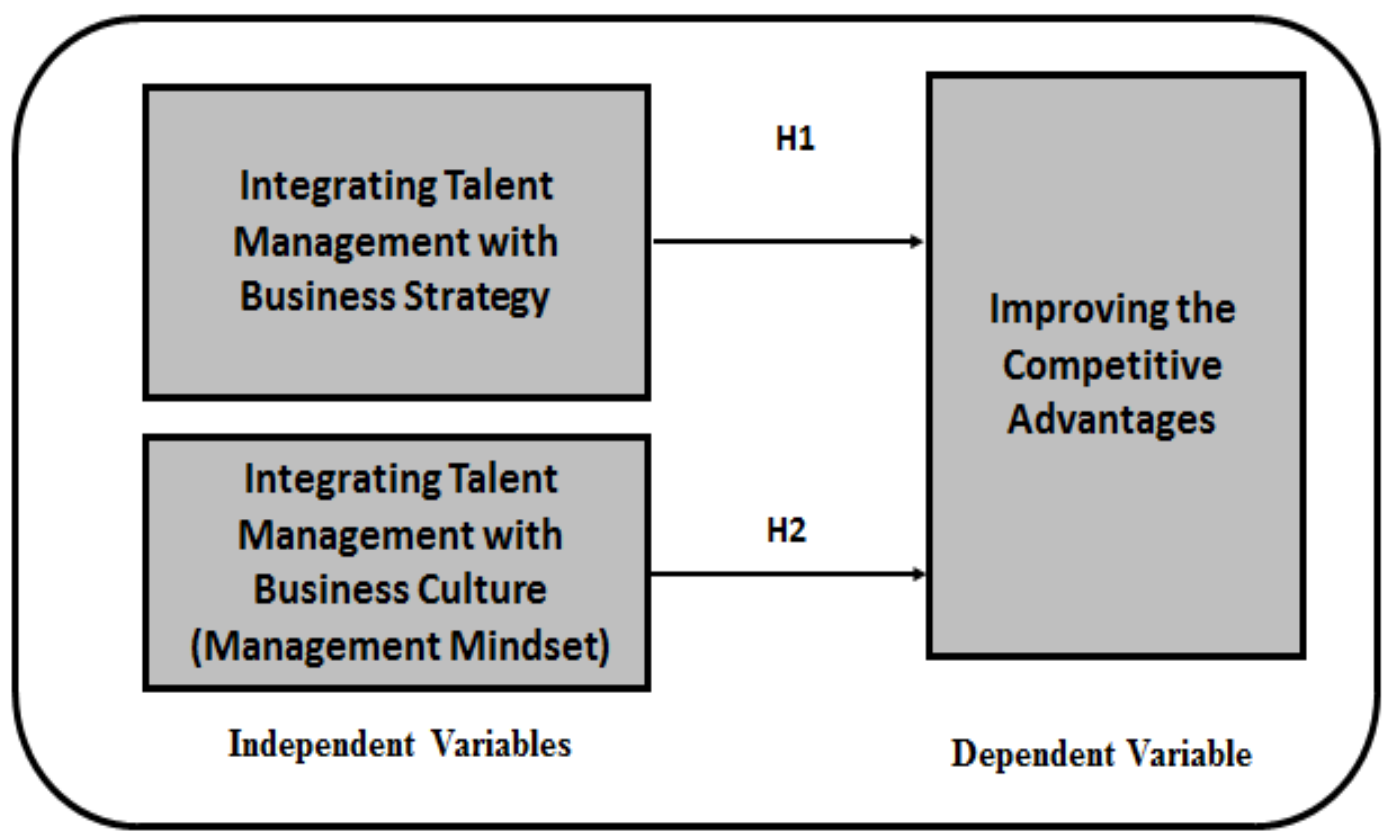

Figure -2

\section{Hypotheses:}

H1: There is a positive significant relationship between Integrating Talent Management strategy with Business Strategy and improving the competitive advantage

H2: There is a significant relationship between Integrating Talent Management with Business Culture and improving the competitive advantage.

\section{Methodology:}

To examine the effect of integrate talent management strategy with business strategy and business culture on achieving the business competitive advantage in multinational corporations for food and beverage in Cairo, Egypt, empirical study was processed. 219 questionnaires were collected from employees and managers who are identified as talented employees by the businesses' managers. Correlation test, linear regression, and multi regression analysis were used to examine the relationship among the independent variables and the dependent variable.

\section{Population and Sample:}

The population embraces all talented employees and managers in the multinational food and beverage companies in greater Cairo. The number of these companies was found to be 16 companies according to the "Chamber of Food Industries" and "Food Business Directory". A thorough research has been carried out to identify the key multinational food and beverage companies in the academic literature. They were: Pepsi (Yapp, 2009; Hills, 2009), Coca-Cola (Mazur, 2014 ; Zamcu, 2014), Nestle (Li, 2015 ; Shanbhag et al., 2016) and Danone (Dejoux, 2013). So the researcher tried to measure the effect of the integrated TM in those companies in Egypt as well. 
INTERNATIONAL JOURNAL OF ACADEMIC RESEARCH IN BUSINESS AND SOCIAL SCIENCES

Vol. 8, No. 7, July 2018, E-ISSN: 2222-6990 (C) 2018 HRMARS

Multi stage sample has been carried out. First, the 16 companies were stratified into two categories; beverages only and food only companies. The companies were then considered as clusters and two companies were picked from each stratum. The companies chosen were the ones that were revealed to be the most investigated by the literature reviewed, Pepsi, Coca-Cola, Nestle, and Danone. Table -1 represents the allocation of the number of the respondents

(Table -1). The number of respondents

\begin{tabular}{|l|l|l|l|l|}
\hline \multirow{2}{*}{ Company } & \multicolumn{2}{|c|}{ Managers } & \multicolumn{2}{c|}{ Employees } \\
\cline { 2 - 5 } & Number* & $\begin{array}{c}\text { Valid } \\
\text { responses }\end{array}$ & Number* & Valid responses \\
\hline Danone & 25 & 21 & 45 & 38 \\
\hline Nestle & 35 & 27 & 50 & 46 \\
\hline Pepsi & 15 & 13 & 37 & 33 \\
\hline Coca-cola & 13 & 12 & 40 & 29 \\
\hline Total & 88 & 73 & 172 & 146 \\
\hline *As identified by the company & \\
\hline
\end{tabular}

\section{Measures:}

(Table-2 ). Study variables and measures

\begin{tabular}{|c|c|c|}
\hline Variable & Measures & References \\
\hline Competitive Advantage & $\begin{array}{l}\text { Financial Outcomes: } \\
\text { (Company Profit - Market Value). } \\
\text { Organizational Outcomes: } \\
\text { (level of productivity - level of } \\
\text { innovation - customer satisfaction) } \\
\text { Human Resources Outcomes: } \\
\text { (Job satisfaction - level of } \\
\text { motivation - level of commitment - } \\
\text { talent turnover) }\end{array}$ & $\begin{array}{l}\text { McCauley \& Wakefield (2006); } \\
\text { Langenegger (2011) } \\
\text { Armstrong (2009); Stefko and } \\
\text { Sojka, (2014) } \\
\text { Khandekar and Sharma (2005); } \\
\text { Boxall and Purcell (2008) }\end{array}$ \\
\hline $\begin{array}{l}\text { Integrating } \\
\text { Management } \\
\text { business strategy }\end{array}$ & $\begin{array}{l}\text { Clear business goals and strategies } \\
\text { Translating business goals into } \\
\text { workforce needs and missing } \\
\text { capabilities } \\
\text { Business Strategy and TM strategy } \\
\text { alignment }\end{array}$ & $\begin{array}{l}\text { Capelli (2008) } \\
\text { William and Slocum (2012) }\end{array}$ \\
\hline $\begin{array}{l}\text { Integrating } \\
\text { Management } \\
\text { culture }\end{array}$ & $\begin{array}{l}\text { Top management commitment } \\
\text { (mindset) } \\
\text { Embedding the TM with the } \\
\text { corporate culture }\end{array}$ & Stefko and Sojka (2014) \\
\hline
\end{tabular}


INTERNATIONAL JOURNAL OF ACADEMIC RESEARCH IN BUSINESS AND SOCIAL SCIENCES

Vol. 8, No. 7, July 2018, E-ISSN: 2222-6990 @ 2018 HRMARS

Questionnaires are to be used for the entire research. All the measures and scale items are to be adopted from the relevant literature with slight modifications to reflect the focus of the study and to be compatible with the context of the research. Table-2 summarizes the items that will be used to measure

\section{Scales and Questionnaires}

The questionnaire was divided into two sections. Section one was consisted of questions to investigate employee personal characteristics including the firm gender, age, job level, year of experience, and taking training course in the organization. Section was consisted of five likert scale for testing the research variables. The respondents were asked to rate their level of agreement on in each statement from (1) never, (2) rarely, (3) unable to rate, (4) sometimes, and (5) always.

The statements were grouped as follow: The employees and managers' perception of the talent management meaning in their workplace in 4 statements are adopted from Stefko and Sojka (2014). The employees and managers' perceptions of how the talent management affect their workplace competitive advantage in 7 statements by scale developed by Boxall and Purcell (2008). How the employees and managers perceive the relationship between their business strategies and the talent management strategies and to what extend both are alignment in 7 statements are adopted by William and Slocum (2012). How the employees and managers perceive that there is an integration and compatibility between their business culture and the talent management in 11 statements are adopted by Kehinde (2012).

\section{Findings}

Questionnaires analyzed through using the "Statistical Package for Social Science (SPSS win 20)". After the entry and recording processes had been completed, all measures then purified by assessing validity and reliability.

Table-3. Cronbach's alpha coefficient

\begin{tabular}{|c|l|c|c|}
\hline ser & \multicolumn{1}{|l|}{ Dimensions } & Reliability & Validity \\
\hline X1 & $\begin{array}{l}\text { Integrating Talent Management with Business } \\
\text { Strategy }\end{array}$ & .878 & 0.937 \\
\hline X2 & Integrated Talent Management Practices & .836 & 0.914 \\
\hline $\mathrm{X}$ & Integrating Talent Management & .843 & 0.918 \\
\hline $\mathrm{y}$ & The Competitive Advantages y & .865 & 0.930 \\
\hline $\begin{array}{l}\text { Total: } \\
\text { Management on the Competitive Advantages }\end{array}$ & .859 & $\mathbf{0 . 9 2 6}$ \\
\hline
\end{tabular}

As shown in (Table-3), the reliability coefficient for the total sample was (0.859), which indicates high degree of reliability for the study sample, which was reflected also by its coefficient that is equal (0.926) and for the independent variables (integrating talent management- $x$ ) the reliability coefficient is $(0.843)$, for the dependent variables (the competitive advantage $-\mathrm{Y}$ ) the reliability coefficient is $(0.865)$. 
INTERNATIONAL JOURNAL OF ACADEMIC RESEARCH IN BUSINESS AND SOCIAL SCIENCES Vol. 8, No. 7, July 2018, E-ISSN: 2222-6990 @ 2018 HRMARS

Table-4. Descriptive statistics for the independent variables of the study

\begin{tabular}{|ll|c|c|c|}
\hline \multicolumn{1}{|c|}{ Items } & Mean & Std. & c.v. \\
\hline $\begin{array}{l}\text { Integrating Talent Management with } \\
\text { Business Strategy x-1 }\end{array}$ & 4.28 & 0.69 & 16.32 \\
\hline $\begin{array}{l}\text { Integrating Talent Management with } \\
\text { Business Culture x-2 }\end{array}$ & 4.17 & .66 & 15.99 \\
\hline
\end{tabular}

(Table-4) indicates the general trend of the total dimensions "Integrating Talent Management with Business Strategy $x-1$ " and "Integrating Talent Management with Business Culture $x-2$ " are towards the (Agreement), with arithmetic mean (4.28) \& (4.17), and the coefficient of variation (16.32) \& (15.99\%) respectively.

Inferential analysis "Testing research hypotheses" Table-5. Pearson correlation between the Integrating Talent Management and The Competitive Advantages

\begin{tabular}{|c|c|c|c|}
\hline Dimensions & Y & $\mathrm{X} 1$ & X3 \\
\hline y-The Competitive Advantages & - & $.831^{* *}$ & $.875^{* *}$ \\
\hline $\begin{array}{lr}\text { x-1.Integrating } & \text { Talent } \\
\text { Management with } & \text { Business } \\
\text { Strategy } & \end{array}$ & & - & $.892 * *$ \\
\hline $\begin{array}{lrr}\text { x-2. Integrating } & \text { Talent } \\
\text { Management with } & \text { Business } \\
\text { Culture } & & \end{array}$ & & & - \\
\hline $\begin{array}{ll}\text { x-(total) Integrating } & \text { Talent } \\
\text { Management } & \end{array}$ & $.891^{* *}$ & & - \\
\hline
\end{tabular}

** Significance level 0.01

The Correlation matrix for the relationship between "the Integrating Talent Management" and "the Competitive Advantages" revealed that there is a significant positive relationship between the two variables at a $p$-value of less than (.01). A positive significant relationship was also indicated between "The Competitive Advantages" and each of "Integrating Talent Management with Business Strategy", and "Integrating Talent Management with Business Culture". The most influential factor in relation to improving the competitive advantage was "integrate talent management with business culture" since it had the highest correlation coefficient. The relationship strength was relatively strong as can be seen from (Table -5). 
INTERNATIONAL JOURNAL OF ACADEMIC RESEARCH IN BUSINESS AND SOCIAL SCIENCES

Vol. 8, No. 7, July 2018, E-ISSN: 2222-6990 @ 2018 HRMARS

Table-6. Linear egression of Integrating Talent Management with Business Strategy $x-1$ on the Competitive Advantages

\begin{tabular}{|c|c|c|c|c|c|c|}
\hline \multirow{2}{*}{ Independent variables } & \multirow[b]{2}{*}{$\beta$} & \multicolumn{2}{|c|}{ t. test } & \multicolumn{2}{|c|}{ F. test } & \multirow[t]{2}{*}{$\mathrm{R}^{2}$} \\
\hline & & Value & Sig. & Value & Sig. & \\
\hline Constant & 1.036 & 7.351 & $0.01 * *$ & 484.797 & $\begin{array}{l}.001^{*} \\
*\end{array}$ & $69.1 \%$ \\
\hline $\begin{array}{l}\text { Integrating Talent Management } \\
\text { with Business Strategy x1 }\end{array}$ & .831 & 22.018 & $0.01^{* *}$ & & & \\
\hline
\end{tabular}

** significant level 0.01

From the above table the following could be indicated:

Coefficient of determination $\left(R^{2}\right)$ indicates that the independent variable "Integrating Talent Management with business strategy" explains (69.1\%) of the total variation in the dependent variable "The Competitive Advantages".

F. Test was used to examine the total quality of the regression model as a whole. It was used with value (484.797) and the $p$-value was calculated. The test indicated that the statistical significance of the model as a whole at significance level of 0.01. To assure the efficiency of the model fitness, the histogram of the dependent variable distribution was drawn. It indicates the goodness of fit of the model. See (figure -3)

Histogram of the dependent variable distribution

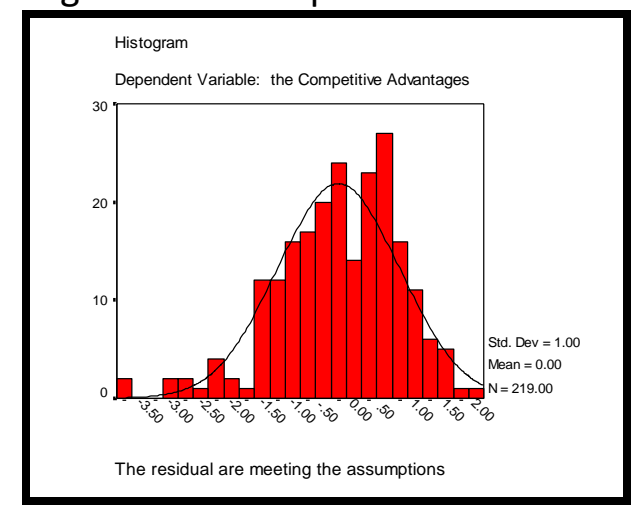

Figure -3

The t-test indicated the statistical significance of both the slope and intercept of the regression equation of regressing the Competitive Advantages on Integrating Talent Management with Business Strategy, as (the $t$ value is 22.018 ) with significance level of 0.01 . With form of the fitted regression equation

The Competitive Advantages $=1.036+0.831$ Integrating Talent Management with Business Strategy

The Effect of Integrating Talent Management with Business Culture $x-2$ on the Competitive Advantages y 
INTERNATIONAL JOURNAL OF ACADEMIC RESEARCH IN BUSINESS AND SOCIAL SCIENCES

Vol. 8, No. 7, July 2018, E-ISSN: 2222-6990 @ 2018 HRMARS

Table- 7. Liner Regression of Integrating Talent Management with Business Culture x-2 on the Competitive Advantages

\begin{tabular}{|c|c|l|l|l|l|l|}
\hline \multirow{2}{*}{ Independent variables } & \multirow{2}{*}{$\beta$} & \multicolumn{2}{|c|}{ t. test } & \multicolumn{2}{|c|}{ F. test } & \multirow{2}{*}{$\mathrm{R}^{2}$} \\
\cline { 3 - 6 } & & Value & Sig. & Value & Sig. & \\
\hline Constant & .808 & 6.445 & $0.01^{* *}$ & 707.600 & $.001^{*}$ & $76.5 \%$ \\
$*$ & & & & & & \\
\hline $\begin{array}{l}\text { Integrated Integrating Talent } \\
\begin{array}{l}\text { Management with Business } \\
\text { Culture x-2 }\end{array}\end{array}$ & .788 & 26.601 & $0.01^{* *}$ & & & \\
\hline
\end{tabular}

$* *$ Significant level 0.01

From the above table the following could be indicated:

Coefficient of determination $\left(R^{2}\right)$ indicates that the independent variable "Integrating Talent Management with business culture" explains (76.5\%) of the total variation in the dependent variable "The Competitive Advantages".

F. Test was used to examine the total quality of the regression model as a whole. It was used with value (707.600) and the $p$-value was calculated. The test indicated that the statistical significance of the model as a whole at significance level of 0.01. To assure the efficiency of the model fitness, the histogram of the dependent variable distribution was drawn. It indicates the goodness of fit of the model. See (figure -4)

Test of the efficiency of the regression model

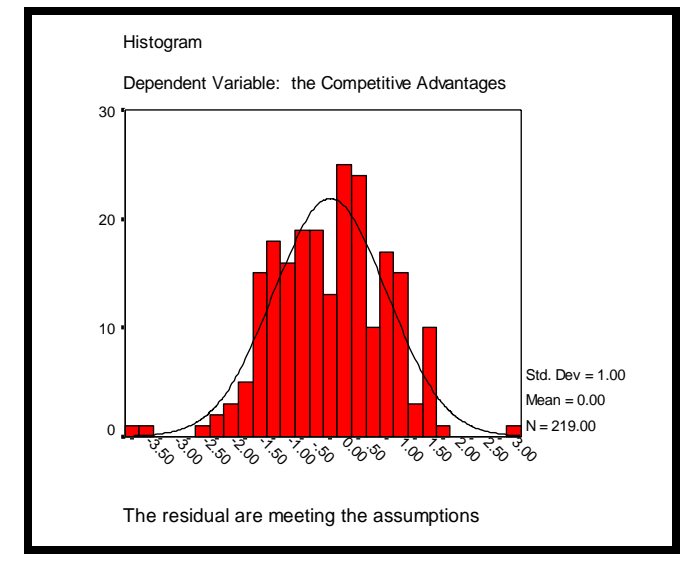

Figure - 4

The t-test indicated the statistical significance of both the slope and intercept of the regression equation of regressing the Competitive Advantages on Integrating Talent Management with Business Strategy, as (the $t$ value is 26.601) with significance level of 0.01 . With form of the fitted regression equation. The Competitive Advantages $=0.808+0.788$ Integrating Talent Management with Business Culture.

The multiple Regression Model

To study the Impact of The three Independent Variables Integrating Talent Management $x$ on The Competitive Advantages y 
INTERNATIONAL JOURNAL OF ACADEMIC RESEARCH IN BUSINESS AND SOCIAL SCIENCES Vol. 8, No. 7, July 2018, E-ISSN: 2222-6990 @ 2018 HRMARS

Table-8. Multiple regression tests for the "Impact of the Integrating Talent Management On The Competitive Advantages"

\begin{tabular}{|c|c|c|c|c|c|c|}
\hline \multirow{2}{*}{$\begin{array}{l}\text { Independent } \\
\text { variables }\end{array}$} & \multirow[b]{2}{*}{$\beta$} & \multicolumn{2}{|l|}{ t. test } & \multicolumn{2}{|l|}{ F. test } & \multirow{2}{*}{$\mathrm{R}^{2}$} \\
\hline & & Value & Sig. & Value & Sig. & \\
\hline Constant & 0.644 & 5.038 & $0.01^{*}$ & 259.611 & $.01^{*}$ & $78.4 \%$ \\
\hline $\begin{array}{l}\text { x1-Integrating Talent } \\
\text { Management with } \\
\text { Business Strategy }\end{array}$ & 0.242 & 3.452 & $0.01 *$ & & & \\
\hline $\begin{array}{lr}\text { x2-Integrating } & \text { Talent } \\
\text { Management } & \text { with } \\
\text { Business Culture } & \end{array}$ & 0.555 & 6.835 & $0.01^{*}$ & & & \\
\hline
\end{tabular}

*Significant at the ( .01$)$ level

From the above table the following could be indicated:

By using the coefficient of determination $\left(R^{2}\right)$, it was found that the independent variable "Integrating Talent Management" explains (78.4\%) of the total variation in the dependent variable "The Competitive Advantages" with constant $\beta$ (0.644). The rest of the variation is due to random error in the equation or perhaps due to other independent variables that were not included in the regression model.

While, F-test was used with value (259.611) and the $p$ value was calculated. The test indicated the statistical significance of the model as a whole at significance level of 0.01 . To assure the efficiency of the model fitness, the histogram of the dependent variable distribution and a $p-p$ plot for the standardized residuals were drawn. They both indicated the goodness of fit of the model. See (figure -5) and (figure- 6).

\section{Test of the Efficiency of the Regression Model}

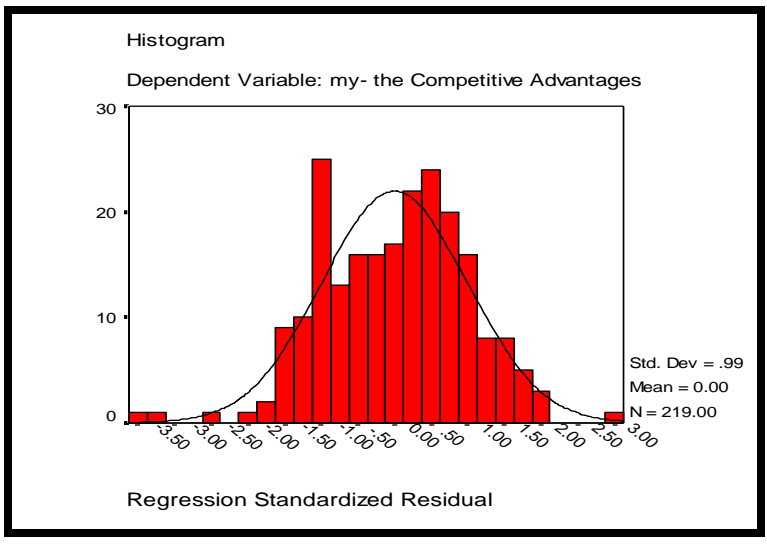

Figure -5

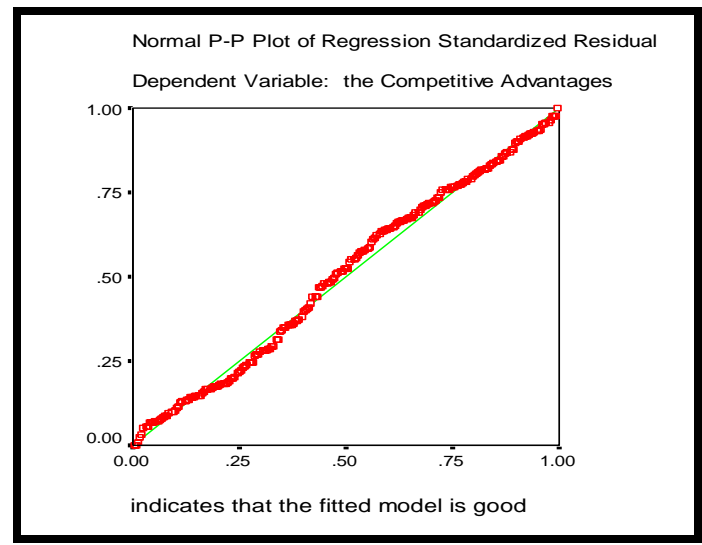

Figure - 6

Also, the t-test indicated the statistical significance of both the slope and intercept of the regression equation of regressing the Competitive Advantages on Integrated Talent Management (Integrating Talent Management with Business Strategy, Integrating Talent Management with Business Culture), as (the t-value is $3.452,6.835$ respectively) with significance level of 0.01 .

The form of the fitted regression equation 
INTERNATIONAL JOURNAL OF ACADEMIC RESEARCH IN BUSINESS AND SOCIAL SCIENCES

Vol. 8, No. 7, July 2018, E-ISSN: 2222-6990 @ 2018 HRMARS

The Competitive Advantages $=0.644+0.242$ Integrating Talent Management with Business Strategy x1 + 0.555 Integrating Talent Management with Business Culture x2

\section{Conclusion}

The study findings depicted that there is a positive significant relationship between integrating the talent management strategy with the "business strategy and business culture" and improving the business competitive advantage. Also the findings revealed that the more the talent management execute and manage into the business context - strategy and culture- the more the talented employees could be managed effectively and improve the competitive advantage.

The results obtained indicate that there is indeed a significant and positive relationship between the integrated talent management and improving the competitive advantage in the multinational organizations in Cairo as hypothesized by the study. These results strengthen previous findings that integrate the talent management strategy with the business strategy (Langenegger, 2011; Shrimali and Gidwani, 2012; Anwar, et al., 2014; Karunathilaka et al.,2015) and business culture (Hatum, 2010; Cutajar, 2012) are essentials to improve the competitive advantage. By examining the effect of the job level (managerial level or operation level) on the talented employees' perception of the integrating talent management and the competitive advantage, the results depicted that there is a significant differences between the managers and employees in their perception of integrating management concept and there is no significance difference between them in their perception of the competitive advantage. Talent management strategies should align with the business strategies in order to identify the needed capabilities and practices that will assist in achieving business strategic goals. Positive talent management practices (attracting, developing, and retaining) talented employees will build a winning culture that people want to belong.

\section{Practical Implications}

- To align business strategy with the talent management strategy means getting business vision, strategic objectives with its related strategies, and the employees' capacity to meet these objectives are moving in the same direction.

- Defining talent is how organizations decide to segment their workforce

- The talent decision making done by managers without allowing the employees to contribute to the decision.

- There is no measurement on the return on investment (ROI) that guides management of talent.

- By providing the possibilities for personal development and the ability to move upwards in the organizational hierarchy, the employees will feel appreciated and respected. Therefore, improving the working environment will be achieved.

\section{Recommendation}

Organizations need to understand who they are regarded as talented employees before implementing the talent management strategies and practices. The talented employees' qualifications and specifications should be extracted from the business strategies.

It is recommended that a culture of talent management must be cultivated in the organization by thorough engagement. It is also recommended that leadership should be obliged to successfully implement the talent management. The implementation of talent management can enhance by adding talent management as one of the key performance outputs to the performance. 
INTERNATIONAL JOURNAL OF ACADEMIC RESEARCH IN BUSINESS AND SOCIAL SCIENCES Vol. 8, No. 7, July 2018, E-ISSN: 2222-6990 @ 2018 HRMARS

Talent management strategies should be developed and aligned with the business strategies in order to identify the needed capabilities and practices that will help in achieving business strategic goals and improve business competitive advantage. As well as positive TM culture will build an effective TM practices, thereby improve business competitive advantage. This study provides an integrated talent management model that con implemented by every organizations in order to develop competitive advantage.

\section{Future Suggestions}

It would be beneficial for future research to consider the following suggestion: Knowledge employee is a person who possess knowledge and utilize it effectively. Knowledge employee is extremely important for optimizing the business competitive advantage. Therefore, knowledge management should be integrated also with the talent management strategies, business strategies, and business culture to develop and sustain competitive advantage. Researchers for future work need to integrate the knowledge management with talent management strategies, business strategies, and business culture to examine the effect of all these variables together on improving the competitive advantage.

\section{Acknowledgments}

I'm truly grateful to my mentor, my supervisor Prof. Dr. Adel Zayed, who has constantly encouraged and given invaluable guidelines and support from the beginning until the end.

\section{Corresponding Author}

Author: Shirley Nagy Ibrahim

Egypt, Cairo University, Faculty of Commerce, Business Administration Department

Email: Shirleyibrahim@gmail.com

\section{References}

Al Ariss, A. \& Cascio, W.F. \& Paauwe, J. (2014), "Talent management: Current theories and future research directions". Journal of World Business, vol. 49(2), pp.173-179.

Anwar A. \& Nisar Q. \& Khan, N. \& Sana, A., ( 2014), "Talent Management: Strategic Priority of Organizations". International Journal of Innovation and Applied Studies, pp.1148-1154.

Armstrong, M. (2009). Armstrong's Handbook of Human Resource Management Practice. USA: Kogan Page Limited .

Avedon, M. J. \& Scholes, G. (2010). "Building competitive advantage through integrated talent managemnt". In \&. D. Silzer R., Strategy-driven talent management (pp. 73-119). San Francisco

Bali, M. and Dixit, S. (2016), "Employer Brand Building for Effective Talent Management", International Journal of Applied Sciences and Management, vol. 2, No. 1, pp. 183-191, 2016

Barney, B. (1991). "Firm resources and sustained competitive advantage" . Journal of Management, vol.17, no.1,pp.99-120.

Bergeron, C. (2004). "Build a talent strategy to acheive your desired business results". In Bergeron, C. Handbook of Business Strategy (pp. 133-139). MCB.

Boxall, P. \& Purcell, J. (2008). Strategy and human resource management. New York: Palgrave MacMillan, 2008, pp.351-368, ISBN 978-1-403992-10-9 Palgrave Macmillan

Canavan, D. (2013). Aligning Strategy and Talent in Creative. Journal of Business Strategy, vol. 34 Iss: 3, pp.24- 32 . 
INTERNATIONAL JOURNAL OF ACADEMIC RESEARCH IN BUSINESS AND SOCIAL SCIENCES

Vol. 8, No. 7, July 2018, E-ISSN: 2222-6990 @ 2018 HRMARS

Cappelli, P. (2008). "Talent on Demand: Managing Talent in an Age of Uncertainty". Boston, USA: Harvard Business Press. pp.661-664

Cheng, W.W. \& Lin, C.H. \& Chu, Y.C. (2011). "Types of Competitive Advantage and Analysis". International Journal of Business and Management. vol.6, no.5, pp.110-104

Collings, D.G. and Mellahi, K. (2009), "Strategic talent management: A review and research agenda". Human Resource Management Review, vol.19, Iss. 4, pp.304-313.

Dejoux, C. (2013) "Talent Management and Leadership Program at Danone China", Journal of the Asia Pacific Economy, vol.1, pp.20-32.

Egerová, D. (2013), "Integrated Talent Management - A challenge or necessity for present management, problems of Management in the 21st century", International Visegrad Fund, Standard Grant No. 21220142, Volume 6, 2013, pp. 4-6

Farley, C. (2005). HR's Role in Talent Management and Driving Business Results. Wiley Periodicals Inc. Published online in Wiley InterScience (www.interscience.wiley.com). DOI 10.1002/ert.2005

Hatum, A. (2010). Next Generation of Talent Management. pp.10-36 , Palgrave Macmillan, London

Heinen, J. \& O'Neill, C. (2004). Managing Talent to Maximize Performance. Wiley InterSience, vol.2, iss.1, pp.67-82.

Hills, A. (2009) "Succession planning - or smart talent management?", Industrial and Commercial Training, Vol. 41 Issue: 1, pp.3-8

Ingham, J. (2006),"Closing the talent management gap: Harnessing your employees' talent to deliver optimum business performance", Strategic HR Review, Vol. 5, Iss 3, pp. $20-23$

Jackson, S.W. (2010). "HR is Business: Achieving Competitive Advantage through Strategic Talent Management". International Journal of Business, vol.2, pp.50-62.

Kehinde, J. (2012), "Talent Management: Effect on Organizational". Journal of Management Research, vol.4, no.2, pp.178-186.

Khandekar, A. and Sharma, A. (2005), "Managing Human Resources Capabilities for Sustainable Competitive Advantage" . An empirical analysis from Indian global organisations", Education + Training, vol. 47 Issue: 8/9, pp.628-639

Langenegger, P.B. (2011). Effectiveness of talent management strategies . European J. International Management, vol. 5, No. 5, 2011, pp. 524- 539

Li, T. (2015), "Nestle Employee Recruitment Research", International Journal of Business and Social Science, Vol. 6, No. 4(1); April 2015

Mazur, B. (2014) "Sustainable Human Resource Management in theory and practice", International Journal of Human Resource Management, Vol. 5 (2), pp. 301-326

McCauley, C. \& Wakefield, M. (2006), "Talent management in the 21st century: Help your company find, develop, and keep its strongest workers", The Journal for Quality and Participation. vol. 29, pp. 4-7.

Nouman, A.A. \& Kousar, T. \& Tanzila, C. (2015). "Talent Mangement as a source of Competitive Advantage". Journal of Asian Business Strategy, Volume 5, Issue 9, 2015, pp. 208-214.

Scullion, H. and Collings, D.G. (2012), "Global Talent Management", Journal of World Business, Volume 45, Issue 2, Pages 105-196

Shanbhag, M. \& Dutt, M.L. \& Bagwe, S. (2013 ), Strategic Talent Management: A Conceptual Analysis of BCG Model, "Imperial Journal of Interdisciplinary Research (IJIR)", Vol-2, Issue-7, 2016 
INTERNATIONAL JOURNAL OF ACADEMIC RESEARCH IN BUSINESS AND SOCIAL SCIENCES

Vol. 8, No. 7, July 2018, E-ISSN: 2222-6990 @ 2018 HRMARS

Sheehan, M. (2012). "Developing Managerial Talent: Expolring the Link between Talent Management and pereceived Performance in (MNCs)" . Europen Journal Of Training and Development, vol.36 (1), pp.66-85.

Shrimali, H. and Gidwani, B. (2012). "Role of Talent Management in Sustainable Competitive Advantage: Rising to Meet Business Challenge". Pacific Business Review International, vol.4 (3), 29-33

Stahl, G. K. \& Bjarkman, I. \& Farndale, E. \& Morris, S. \& Paauwe, J. \& Stiles, P. and Trevor, J. (2012) Six principles of effective global talent management. MIT Sloan Management Review, vol.53 (2). pp. 25-32.

Stefko, R. and Sojka, L. (2014), "Position of talent management in the context of the organizational functions". European Scientific Journal, vol.1, pp.347-356.

Tansley, C. (2011). "what do we mean by the term "talent" in talent management?", . Industrial and Commercial Training, Vol. 43 Issue: 5, pp.266-274.

Tarique, I. and Schuler, R.S. (2010). "Global talent management and global talent challenges: strategic opportuinities for IHRM". Journal of World Business, vol.46 (2011) pp.506-516.

Ulrich, D. (2008), Talent: Making people your competitive advantage. (1st ed.) John Wiley \& Sons, Inc. Human Resources Management, winter2008, vol.47, No.4, pp.829-850

Wahyuningtyas, R. (2014). "An Integrated Talent Management System: Challenges for Competitive Advantage". International businee managemnt, vol.10 ISSN:1993-5250, pp.194-205.

William, J.F. and Slocum, J.W. (2012), "Top management talent, strategic capabilities". Organizational Dynamics, vol.41, (2012) pp.183-193.

Yapp, M. (2009) "Measuring the ROI of talent management", Strategic HR Review, vol. 8 Issue: 4, pp.5-10

Zamcu, E.G. (2014), "Trends and challenges in the modern HRM- Talent Management", Journal of management research, vol. II, issue (2), pp. 173-180

Zhang, S. and Bright, D. (2012). "Talent definition and talent management recognition in Chinese private owned enterprises", Journal of Chinese Entrepreneurship, vol. 4 Issue: 2, pp.143-163 